\title{
Pig (Sus scrofa domesticus) dung and their associated fungi: Potential candidates for bio-remediation and nutrients improvement of crude oil contaminated soils
}

\author{
DAVID NWAZUO ENYIUKWU ${ }^{1, \bullet}$, INENESIT N. BASSEY ${ }^{2, \bullet \bullet, ~ G R A C E ~ A M A R A C H I ~ N W A O G U ~}{ }^{1}$, \\ N.U. ASAMUDO ${ }^{2}$, LWANGA AZUBUIKE CHUKWU ${ }^{3, \bullet \bullet \bullet, ~ E . A . ~ M O N D A Y ~}{ }^{4}$, JACQUELINE O. MARANZU ${ }^{5, \bullet \bullet \bullet \vee ~}$ \\ ${ }^{1}$ Department of Plant Health Management, Michael Okpara University of Agriculture. Umudike PMB 7267, Umuahia, Abia State, Nigeria. \\ "email: enyidave2003@gmail.com \\ ${ }^{2}$ Department of Botany and Ecological Studies, University of Uyo. PMB 1017 Uyo, Akwa Ibom State, Nigeria. ^ email: basseyinemesit17@yahoo.com \\ ${ }^{3}$ Department of Agricultural Technology, Faculty of Agriculture, Akanu Ibiam Federal Polytechnic. Uwana, Afikpo, Ebonyi State, Nigeria. \\ •vemail: lwangachukwu@gmail.com \\ ${ }^{4}$ Department of Microbiology, University of Uyo. PMB 1017 Uyo, Akwa Ibom State, Nigeria \\ ${ }^{5}$ National Environmental Standards Regulations Enforcement Agency, Southeast Zonal Headquarters. Port Harcourt-Owerri Road, Owerri Imo State, \\ Nigeria. ${ }^{\vee v \vee}$ email: ojmaranzu@yahoo.com
}

Manuscript received: 23 May 2021. Revision accepted: 17 July 2021.

\begin{abstract}
Enyiukwu DN, Bassey IN, Nwaogu GA, Asamudo NU, Chukwu LA, Monday EA, Maranzu JO. 2021. Pig (Sus scrofa domesticus) dung and their associated fungi: Potential candidates for bio-remediation and nutrients improvement of crude oil contaminated soils. Biodiversitas 22: 3276-3286. Pig dung a common agro-waste material in Nigeria is associated with many fungal saprophytes. Rising oil spillages and pollution in Nigeria have made cultivation of affected agro-lands un-rewarding. Potentials of pig dung in mitigating crude oil pollution in agro-soils are herein studied. The objectives of this study were to characterize the fungal profile associated with wet and dry dung of pig. And to evaluate the remediating impacts of pig dung and their associated fungi on crude oil and heavy metals contents, physicochemical properties, and phytotoxicity of crude oil polluted soils. Coprophilous fungi were isolated from wet and dry dung by moist chamber technique and identified. Utisoil from Umudike was polluted with crude oil, amended with 10-40\% of dry pig dung and sown with soybean (Glycine max L.). The amended and un-amended crude oil contaminated utisols were analyzed to reduce crude oil and heavy metals contents; and physicochemical properties at planting, and harvesting, respectively, using classical and spectrometric methods, and the extent of crude oil and heavy metals removal determined. The percentage germination, height, number of leaves, leaf color, vigor, and biomass of the test crop were recorded from the test plant. The results showed that Aspergillus candidus, Sclerotium sp., Absidia sp., Acremonium sp., Candida tropicalis, C. pseudotropicalis, and Rhizopus oryzae were consistently isolated from the dry dung specimen than the wet one. The results also indicated that the treatments significantly reduced the treated soils' crude oil and heavy metals contents. It revealed that values obtained for residual oil or heavy metals contents of the treated soils and crop performance were inversely and directly related to levels of soil amendment respectively. Crop performance in the amended soil remained statistically $(\mathrm{P} \leq 0.05)$ higher compared to the control. Soil analyses showed that the dung treatments significantly increased the values of nitrogen, phosphorus, potassium, organic carbon, etc. in a directly proportional manner. Therefore, pig dung and their associated fungi hold strong potentials as cheap eco-friendly platforms to provide and stimulate microbial growth, hasten degradation and removal of crude oil and heavy metals from contaminated soils; and thus permit and sustain good performance of arable crops.
\end{abstract}

Keywords: Bio-stimulation, coprophils, decomposers, pollution, mycoflora, pig dung

\section{INTRODUCTION}

Pig dung (excreta) consists of macerated undigested remains of consumed food such as cellulose, hemicelluloses, lignin and other waste products excreted by the animals. In rural areas of India, dry dung is still used as fuel for cooking and to generate smoke for repelling insects. However, in most cases, they are used as soil amendments to modulate low soil $\mathrm{pH}$ caused by buildup of acidic radicals (hydrogenium and alumina) from multiyears of continuous cropping (DPI 1999; Zhang 2017) and to improve soil fertility. Dung is rich in carbohydrates, protein, some water-soluble vitamins and mineral ions (Gupta et al. 2016). Being rich in carbon, nitrogen and moisture, pig dung is a good substrate that supports the growth of bacteria and various fungi, that participate in nutrient recycling in the ecosystem (Abdullah 1982; Bills et al. 2013; Zhou et al. 2016; Samuel et al. 2017).

Fungi are one of the most important organisms that degrade waste matter on earth (Cohen and Hader 2009; Countryside 2012). They recycle composts, manures and agro-wastes including dung to the soil in forms that can be re-absorbed and used by higher plants. Coprophilous fungi in amended soils thus contribute in no small measure as bio-fertilizers to improving soil texture, aeration and soil nutrient status for better crop performance (Amaechi et al. 2018); or as pest repellants (Gupta et al. 2016). Lu et al. (2014) reported that some dung-inhabiting fungi demonstrated strong nematicidal activity against Caenirhabditis elegans and Meloidogyne incognita, releasing toxic monoterpenes that acted by rupturing eggs 
and cuticles of these parasites (Echeverrigarray et al. 2010; Enyiukwu and Awurum 2013).

One of the major challenges, facing human societies in modern times is environmental pollution, especially crude oil spillages (Adams et al. 2017). In Nigeria, rising demand for oil-based energy has led to increased exploration and drilling for crude oil especially in the Niger delta area. However, infrastructure and equipment failures during such operations in upstream, downstream and along value chain lines or transportation channels, have resulted in widespread oil spillages and environmental pollutions, around communities of operations (Erdogan et al. 2011; Udeani et al. 2012; Naowasarn et al. 2016; Ugwoha et al. 2020). Statistics revealed that 7000 oil spill cases occurred in the Niger delta area in the last 5 decades; with about 37 million liters (240, 000 barrels) of oil discharged into the ecosystem per year (Amnesty International 2018). Hydrocarbons are harmful to ecosystems and their associated food chains (Kumar and Kuar 2019). So far, over $60 \%$ of households in the area are food insecure due to massive reductions in arable crop yield and untold losses of shrimps and fishes that attend this pollution. Even quality of the ones produced is not left unaffected. About $30-40 \%$ loss of protein and vitamin C contents in vegetables and tubers has been reported (Nwagbo 2017). These factors put together, have made the Niger delta one of the most polluted areas in the world (Adekunle and Ataga 2014; Amnesty International 2018).

Several physical and chemical strategies have been used to remediate petroleum-contaminated soils. These include physical and chemical reclamations. Physical strategies are costly and eco-unfriendly. However, chemical reclamation approaches though effective, have been reported to be attended by anthropogenic eutrophication among other shortfalls. Bio-remediation is a technology whereby environmental pollutants are degraded and cleaned up through microbial activity (Akhtar et al. 2020; Ugboma et al 2020; Zhang et al. 2020). This kind of approach to oil clean-up has the advantages of being non-invasive, rapidacting, cost-effective, eco-friendly and supportive to soil fauna and flora by increasing nutrient availability and uptake by plants (Erdogan et al. 2011; Udeani et al. 2012; Nwaogu et al. 2015). Fungi such as Mucor sp. Trichoderma sp., Cladosporium sp., Fusarium spp., Rhizopus sp., Penicillium sp., Aspergillus niger, Candida utilis, $C$. tropicalis, C. bobicola, etc. commonly associated with dung (Bell 1983; 2005) have been reported to play immense role in bioremediation of oil pollution-damaged soils and riverine environments. These coprophils can utilize crude oil as a source of calories (Obire et al. 2008; Orji et al. 2012; Gupta et al. 2016; Samuel et al. 2017). Samuel et al. (2018) reported that remediating crude oil polluted soils with $10-40 \%$ of dry pig dung not only increased the population of fungal heterotrophs in the treated soil, but also increased available nutrients, and reduced its total petroleum hydrocarbon load by $84.60 \%$ compared to $25.69 \%$ recorded in the untreated control experiment. Similar interventions in other studies led to increased growth, better overall performance and increased yield of bean and maize on petroleum contaminated soils compared to the control where the test plants were chlorotic and completely failed to grow (Obire et al. 2008; Imran et al. 2014; Samuel et al. 2018). Coprophils associated with pig dung underpin their efficacy in remediating crude oil-contaminated soils (COCS) (Obire et al. 2008). Their mode of action is suggested to include secreting a pool of extracellular enzymes capable of degrading stubborn bonds in polycyclic aromatic hydrocarbons (PAH) and total petroleum hydrocarbons (TPH) in soil (Bada et al. 2019).

Crude oil usually contains some amounts of heavy metals such as lead, chromium, cadmium, zinc, copper, manganese, and arsenic (Iwegbue 2011). Association of COCS with increased presence of these heavy metals (or metalloids) over time has been reported (Adesina and Adelesoye 2014; Adams et al. 2017; Giwa and Ibitoye 2017). Heavy metals are found toxic to biological systems by reducing soil microbial population, stunting growth of plants and bio-accumulating in adipose tissues of organisms along the food chain. Cadmium denatures protein and inhibit cell division, lead inhibits enzymes transcription, copper is known to disrupt cellular function while zinc decreases biomass accumulation of affected plants (Giwa and Ibitoye 2017). Bio-stimulation of COCS with rice husk or animal dung has been reported. Fungi associated with these agro-waste materials secrete metalbinding proteins from their filaments, immobilizing heavy metals in soils (Adams et al. 2017; Akhtar et al. 2020). These proteins provide cheap electron acceptors that participate in degradation, chelation, immobilization reactions and bio-sorption of heavy metal ions to less toxic forms (Adams et al. 2017; Giwa and Ibitoye 2017).

The information on type and ability of coprophils associated with pig dung to remediate crude oil and heavy metals-contaminated soils especially in Southeastern parts of Nigeria is still limited; raising urgent need to catalog them. With the increased pig production in Southeastern Nigeria, challenges to managing huge amounts of dung discharged from piggeries are also increasing. Given the need to urgently and viably find low-cost methods of solving the twin problems of pig dung disposal on the one hand and crude oil pollution in soils in Niger Delta belt of Nigeria on the other; this work, therefore, aimed to: (i) Isolate, identify and determine incidence of coprophilous fungi from wet and dry dung samples from a piggery in Uyo, Akwa Ibom State, Southeast Nigeria, (ii) Evaluate the potentials of these pig dung fungi as possible candidates for bioremediation of crude oil contaminated soils (COCS) in the area, (iii) Determine the effects of pig dung and their associated fungi on levels of heavy metals in COCS and, (iv) Assess the effects of the treatments as soil amendments for increased nutrient status of COCS.

We, therefore, hypothesize that: (i) Differential moisture contents of pig dung affect the type and incidence of fungi associated with wet and dry pig dung samples; (ii) Pig dung fungi reduce the amount of crude oil and heavy metals in COCS and, (iii) Pig dung and their associated fungi improve nutrient status as well as arable crop performance in crude oil-contaminated soils. 


\section{MATERIALS AND METHODS}

\section{Experimental sites and locations}

The in vitro experiment was carried out in the Microbiology Laboratory of the Department of Botany and Ecological Studies, University of Uyo. Nigeria. Uyo (latitude $5^{\circ} 03^{\prime} 04^{\prime \prime} \mathrm{N}$, longitude $7^{\circ} 56^{\prime} 00^{\prime \prime} \mathrm{E}$ and 45 meters above sea level) the capital city of Akwa Ibom State, is located in the rainforest agro-ecological zone in the Niger Delta belt of Nigeria. The in vivo eco-remediation, phytotoxicity and nutrient evaluation experiments were carried out at the greenhouse of the Michael Okpara University of Agriculture, Umudike. Umudike Abia State, located at latitude $5^{\circ} 29^{\prime} \mathrm{N}$ and longitude $7^{\circ} 33^{\prime} \mathrm{E}$ is 69.20 $\mathrm{km}$ from Uyo; and stands at an altitude of 121.08 meters above sea level.

\section{Source of experimental materials, soil and dung specimens}

Wet and dry specimens of pig (Sus scrofa domesticus) dung were collected from a large commercial piggery in the outskirt of Uyo, Akwa Ibom State, Nigeria with a sterile (dipped in $70 \%$ alcohol) scalpel. They were put separately in large brown envelopes and taken to the Microbiology Laboratory of the University of Uyo for further analysis. Crude oil was obtained from Eleme oil field at Eleme Local Government Area of Rivers State, Nigeria. The seeds of soybean (Glycine max L.) used for this study were (TGX 1840-10E) developed by the International Institute of Tropical Agriculture (IITA). The seeds were obtained from the Research and Training (R\&T) Unit of the Crop and Soil Sciences, Michael Okpara University of Agriculture, Umudike, Nigeria. The soil sample (uncontaminated, un-amended soil) was collected from the Michael Okpara University of Agriculture, Umudike, Research Farm at a depth of $6 \mathrm{~cm}$ with a soil auger and bulked.

\section{Preparation of culture medium (PDA)}

About 40 grams of dehydrated potato dextrose agar (PDA) (OxoidTMThermoScientific Product, England, UK) medium was dissolved in $1000 \mathrm{ml}$ of sterile distilled water in $1000 \mathrm{ml}$ conical flask to which $0.5 \mathrm{ml}$ of $10 \%$ lactic acid was added, and then stirred vigorously before the flask was stoppered with a foiled cotton wool and autoclaved at 15 pounds per square inch (Psi) $\left(152 \mathrm{cmHg}, 120^{\circ} \mathrm{C}\right)$ for 15 minutes (Enyiukwu et al. 2021).

\section{Isolation and identification of fungi}

The procedure adopted by Thilagam et al. (2015) was used for this study. The tissues of both wet and dry specimens of the dung collected from the piggery were plated by blotter method in three determinations, and incubated for 10 days at $27^{\circ} \mathrm{C}$ in an inoculation chamber. Bits of different mycelial growths that grew out from the plated dung tissues were picked with a sterile inoculation needle, sub-cultured repeatedly on PDA medium in $9 \mathrm{~cm}$ diameter Petri dishes to obtain pure cultures of the isolates which were later maintained on PDA slants in McCarthy bottles (Enyiukwu et al. 2021).
The color and colony characteristics of the isolates were observed and recorded. Slides of the organisms prepared from their respective pure cultures were fixed over a spirit lamp's flame, mounted and examined under a low-high power compound microscope. The morphological characteristics of the conidia and hyphal structures (growth pattern, spores shapes, and sizes) of the organisms were compared and their identities confirmed with reference to the illustrated genera of imperfect fungi by Barnett and Hunter (1995).

The experiment was set up in a completely randomized design (CRD) consisting of 2 treatments replicated 3 times. The whole experiment was repeated twice. The incidence of the fungal divisions or species was assessed according to the formula adopted by Enyiukwu and Awurum (2012) as modified as:

$\%$ Incidence $=\frac{n \times 100}{N}$

Where:

$\mathrm{N}$ : Number of times a species (division) was isolated per treatment per replicate

$\mathrm{N}$ : Total number of times the species/division were isolated per treatment per replicate

\section{Evaluation of pig dung for bioremediation of crude oil polluted soil}

Test for crude oil utilizing potentials of pig dung coprophils

At 17 weeks after amendment with pig dung, ten grams of each dung-amended crude oil contaminated soil (COCS) were collected and put in a $50 \mathrm{ml}$ beaker and covered with foiled cotton-wool, and then autoclaved at $121^{\circ} \mathrm{C}$ for 20 minutes to kill off and stop further activities of the fungal organisms. The samples were separately transferred into a separating funnel and the residual crude oil was extracted with toluene into a flask. The funnel was cocked tightly, and tilted for 7 minutes. Occasionally the flasks and their contents were shaken and refluxed to let out air, and then allowed to stand for 30 minutes. The filtrates (residual oil + toluene) were collected in sample bottles and analyzed by spectrometric method by diluting the filtrates with known volumes of toluene and reading the absorbance at $420 \mathrm{~nm}$. A standard (crude oil) of known volume was also run at $420 \mathrm{~nm}$ and a calibration curve was generated from which the residual crude oil was determined from the respective levels of remediated COCS using the formula adopted by Samuel et al. (2018) as:

$$
\text { Residual oil }=\frac{\text { IVS } \times \text { GR }}{\text { WT }}
$$

Where:

WT : weight of soil sample

IVS : Initial volume of extracting solvent (toluene)

GR : absorbance $\mathrm{x}$ slope of the standard curve

The bio-remediation effects of the fungi from the pig dung amendment on the COCS were calculated as percentage reduction of crude oil contents of the treated soils compared to the untreated contaminated soil as: 


\section{$\%$ Reduction of crude oil content $=$ Crude oil applied - crude oil recovered x 100 Crude oil applied}

\section{Test for heavy metals in soil and soybean tissues}

One gram of COCS and unpolluted soil and digested dried soybean root tissue samples (contaminated and uncontaminated) were separately charred on a hot plate and then ashed in a furnace (Model 186A, Fisher Scientific Co.). The different ashes and respective soil specimens were separately dissolved in $1 \mathrm{~N}$ nitric acid and the resulting solutions were analyzed with Atomic Absorption Spectrometer (AAS) (Model: AA 7000, Shimadzu, Japan) for their heavy metal elemental (cadmium, chromium, lead, copper, manganese and mercury) contents based on their absorbances from the AAS machine at $602 \mathrm{~nm}$ wavelength. The comparative amounts of the elements were determined from a calibration curve generated from running standards at the same wavelength.

The bio-remediation effects of the pig dung and its associated fungi on the COCS were calculated as percentage reduction of heavy metal contents of the test plant and soil samples compared with the untreated controls based on the methods adopted by Adams et al. (2017) and Giwa and Ibitoye (2017) as:

$$
\% \text { reduction of heavy metal content }=\frac{(A-B)}{B} \times 100
$$

Where:

A : Concentration of respective heavy metal ions in the controls

B : Concentration of respective heavy metal ions in treated samples of soybean root or soil

\section{Eco-toxicity remediation test}

The methods adopted by Naowasarn and Leungprasart (2016) and Samuel et al. (2018) were used for the study. Fifty milliliters of crude oil were added to $2 \mathrm{~kg}$ heatsterilized topsoil in $10 \mathrm{~cm}$ diameter plastic pots. To this $0 \%, 10 \%, 20 \%, 30 \%$, and $40 \%$ (w/w) of dry pig dung was separately added; mixed thoroughly with a trowel, and allowed to stand for 4 weeks (to make for stimulation and growth of heterotrophic fungi from the pig dung). Thereafter, soybean 3 seeds were sown per pot, and the pots watered every day. Two weeks after planting (WAP), the seedlings were thinned to two per pot, observed daily and records of the germinated seeds were taken per treatment per replicate. Four WAP, number and color of leaves of the seedlings, seedling vigor, and plant height (measured with a meter rule) were also taken per pot/replicate. At $10 \mathrm{WAP}$ the mature soybean plants were uprooted and their fresh weight (biological yields) was measured with a digital balance. The experiment was set up in a randomized complete block design (CRD) consisting of 5 treatments with 4 blocks. The influence of the dung fungi on toxicity of crude oil polluted soil was assessed by visual assessment of the vigour of the individual seedlings using the descriptive scale of 1-8 as adopted by Enyiukwu and Ononuju (2016): 1: Seedling has very poor vigor, 2: Seedling mildly vigorous, 4: seedling moderately vigorous,
6: seedling highly vigorous, and 8: seedling very highly vigorous. While the leaf colour was assessed using the descriptive scale of 1-4, namely: 1: Chrorotic (yellowish), 2: Greenish, 3: Dark green, 4: Very dark green.

The effects of the dung-borne fungi on the improvement of health of the crude oil contaminated soil were taken as improvements in seed germination, seedling vigor, and general performance of the seedlings on various levels of the pig dung-remediated soil compared to the unremediated control experiment.

\section{Soil test and analysis}

Samples of the unpolluted and soils polluted with crude oil and then remediated with respective levels of pig dung were enveloped and taken to the Soil Science Laboratory, MOUAU for analysis. The respective samples were collected at planting (week 4) and at harvest (Week 13) and analyzed on triplicate determinations for basic nutrients based on the procedure adopted by Ikeogu and Nwofia (2013).

\section{Data analysis}

Analysis of variance (ANOVA) used for data analysis was done with general linear model procedure in Genstat Release (Windows/PC Vista, version 12.10) computer program at significant level of $5 \%$. Means were separated and compared using Fishers LSD at 5\% probability.

\section{RESULTS AND DISCUSSION}

\section{Results}

Results of the present study revealed that Aspergillus candidus, Sclerotium sp., Absidia sp., Candida tropicalis, C. Pseudotropicalis and Rhizopus oryzae were found associated with both the wet and dry specimens of the pig dung, but at varying proportions. The incidences of the various individual fungal isolates on the assayed materials are also captured. The highest frequency of occurrence of the isolates on the dry dung material was $C$. tropicalis (63\%), A. Candidus (48\%), Asidium sp. and Acremonium sp. $42 \%$ and $40 \%$ respectively, and C. pseudotropicalis whose incidence was least $(5 \%)$. On the other hand $C$. pseudotropicalis, Sclerotium sp., R. oryzae, A. Candidus, Acremonium sp. recording incidence profile of $80 \%>22 \%$ $>20 \%>16 \%$ and $5 \%$ represents the highest and least in that order on the wet pig dung specimen. Generally, with the exception of $C$. tropicalis and $R$. oryzae, the incidences of all the fungal isolates were higher in the dry samples than in the wet test dung specimens (Figure 1).

Results of the divisions and class of the fungal species associated with wet and dry specimens of the pig dung revealed that the species of mycoflora associated with pig dung belonged to Ascomycota, Basidiomycota and Mucoromycota (Zygomycota). In overall, it showed that 4 out of the 7 species associated with pig dung (57.14\%) in this study were members of Ascomycota; making them the highest occurring fungal division isolated from the test specimens. This was followed by members of Mucoromycota to which 2 out of the seven species $(28.57 \%)$ belonged. Both Ascomycota and Mucoromycota (Zygomycota) were 
significantly $(\mathrm{P} \leq 0.05)$ greater in occurrence on the dung samples than the members of the division Basidiomycota which was recorded in 1 out of the seven coprophils $(14.27 \%)$ isolated from the test specimens and hence the least occurring fungal division. The results also showed that fungi of the classes Mucoraceae ( $R$. oryzae and Absidia sp.) and Saccharomycetes (C. tropicalis and $C$. pseudotropicalis) were the highest occurring mycoflora on the dung specimens while all other classes had a species a piece (Table 1).

Results of the residual content of crude oil and the corresponding level of removal of hydrocarbon pollutants from the pig dung-treated contaminated soil are presented in Table 2. The results indicated that all the levels of soil amendment with pig dung significantly $(\mathrm{P} \leq 0.05)$ afforded fungal organisms that effectively and efficiently degraded the petroleum hydrocarbon compared to the untreated polluted control. The highest level of removal of crude oil from the contaminated soil $(81.09 \%)$ was achieved at $40 \%$ treatment with pig dung on the COCS; followed by 70 . $86 \%$ and $59.29 \%$ for $30 \%$ and $20 \%$ levels of soil amendment respectively. However, $52.84 \%$ recorded from $10 \%$ pig dung amended soil represents the lowest level of crude oil removal from the soil. The pattern of crude oil removal from the pig dung amended COCS showed a dosedependent strategy (Table 4).

Results of heavy metal contamination of the test soils and soybean at harvest indicated that the heavy metals with highest presence in both un-amended crude oil contaminated soil and soybean plant specimens were iron (1001.21 ppm, $984.19 \mathrm{ppm})$ followed by zinc (163.19 ppm, $151.16 \mathrm{ppm}$ ), and then cadmium (45.06 ppm, $37.09 \mathrm{ppm}$ ) while arsenic with $2.17 \mathrm{ppm}$ and $1.89 \mathrm{ppm}$ respectively was the least. Also, the highest mean concentration of all the heavy metals was recorded in the control experiments which was $176.95 \mathrm{ppm}$ and $171.95 \mathrm{ppm}$ for soil and plant specimens respectively. The amendment of the COCS with pig dung led to significant reductions in mean heavy metal contents of the test soil and plant specimens. Amendment of the crude oil contaminated soil with $40 \%$ pig dung led to the highest reduction of mean contents of heavy metals in the soil and soybean to $58.95 \mathrm{ppm}$ and $51.14 \mathrm{ppm}$ respectively. This was closely followed by $30 \%$ pig-dung amendment which had 89. 08 ppm and $85.67 \mathrm{ppm}$, while, $106.57 \mathrm{ppm}$ and $101.90 \mathrm{ppm}$ obtained respectively from the soil and soybean seedling samples exposed to $10 \%$ amendment were the least. The result established that all the treatments significantly reduced heavy metal contamination of the soil and soybean better than the control. Also, the reduction of the heavy metals increased with the concentration of pig-dung amendment in the treated soil or seedling (Table 3 ).

Results of this present study indicated that different soil amendment regimes significantly $(\mathrm{P} \leq 0.05)$ affected the germination of seeds of soybean and the vigour of the emerged seedlings. It showed that the level of seed germination and emergence of seedlings ranged between $71.20 \%-85.96 \%$. COCS amended with $40 \%, 30 \%, 20 \%$, and $10 \%$ levels of dry pig dung had $85.96 \%, 80.23 \%$, $74.08 \%$, and $71.20 \%$ seed germination respectively which were significantly $(\mathrm{P} \leq 0.05)$ greater than $24.13 \%$ obtained from the control experiment. Similarly, the percentage seedling vigor ranged from $58.20 \%-75.58 \%$ for the corresponding $10 \%-40 \%$ concentration of amendment of the COCS with pig dung. Amending the COCS with $40 \%$ concentration of pig dung resulted in the highest seedling vigor of $75.87 \%$. This was followed by $74.28 \%$ and $67.71 \%$ obtained from $30 \%$ and $20 \%$ treatments respectively. The least effects on seedling vigor (58.20\%) due to the treatments, was recorded on seedlings growing on $10 \%$ pig dung amended COCS. All the levels of soil amendment sufficiently $(\mathrm{P} \leq 0.05)$ improved the assayed attribute better than the control experiment which recorded only $21.33 \%$ for seedling vigor. The seed germination and seedling vigor level increased with increased level of amendment of COCS with pig dung (Figure 2).

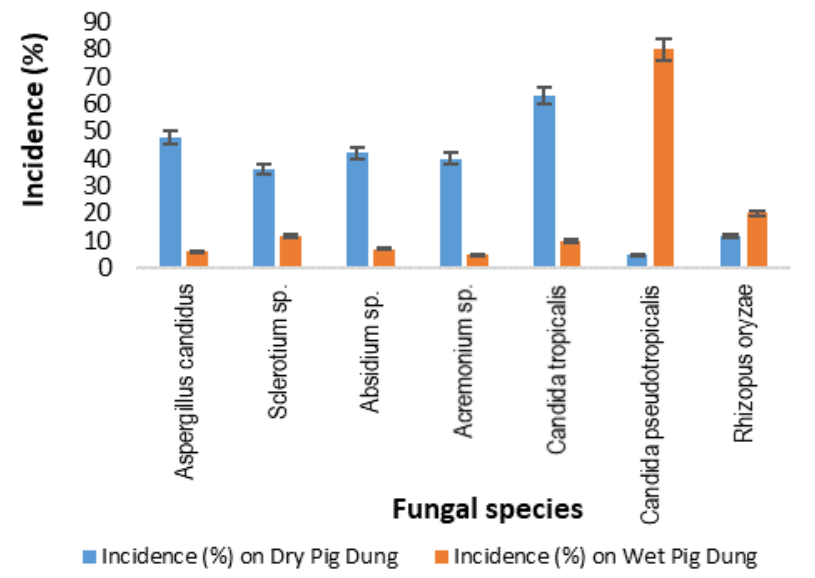

Figure 1. Fungal species (\%) observed on wet and dry specimens of the pig dung

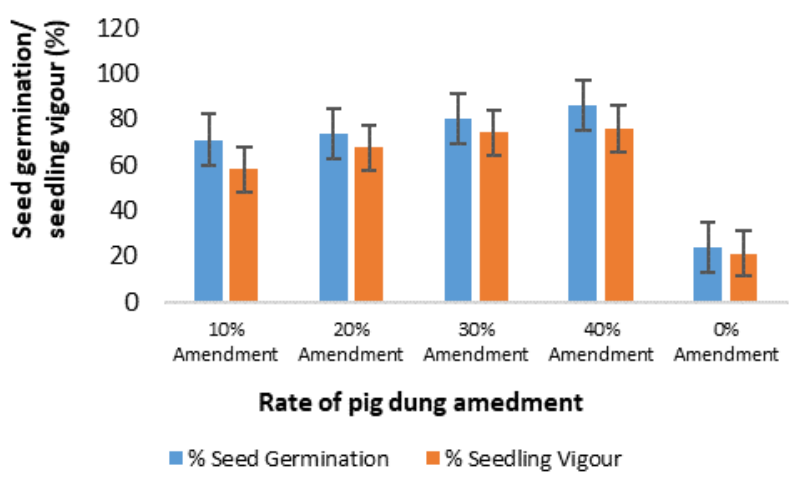

Figure 2. Seed germination (\%) and seedling vigour of soybean seeds sown in pig dung-amended COCS 
Results obtained from this study on the effects of the different levels of the soil amendment on the performance of the treated crop grown on the pig dung amended COCS showed that plants growing on $40 \%$ pig dung amendment COCS had the highest plant height $(47.19 \mathrm{~cm})$, number of leaves (16), darkest green leaf color and highest biomass accumulation (64.24 g). This was closely followed by $30 \%$ amendment regime which gave plant height $(40.50 \mathrm{~cm})$; number of leaves (15), leaf color (dark green) and fresh weight of biomass $(61.18 \mathrm{~g})$. The trend was similar for $20 \%$ concentration of pig dung-amendments on the crude oil contaminated soils which gave $59.68 \mathrm{~g}$ of fresh produce amongst others. On the other hand, the least values of $34.72 \mathrm{~cm}, 12$, and $53.21 \mathrm{~g}$ were recorded respectively for plant height, number of leaves per plant and fresh weight per plant for the $10 \%$ pig dung-amended COCS. However, all the treatments performed significantly $(\mathrm{P} \leq 0.05)$ better than the control experiments for the respective test parameters. Generally, these parameters were found to improve in direct proportion to level of soil amendments (Table 4).

Results of soil texture and nutrient composition showed that the soil of the University Research Farm is sandy loam. It indicated that at planting of the test crop (soybean) (Week 1), the soil was low in Sodium, Potassium, Magnesium and total Nitrogen contents. It also indicated the presence of moderate levels of calcium, organic carbon and organic matter, but high in amount of phosphorus. These nutrients were found to increase with concentration of amendment of the COCS with pig dung. However, analysis of these parameters after harvesting of the test crop (at week 13) indicated that these nutrients were significantly lower to their corresponding values at planting, but sufficiently $(\mathrm{P} \leq 0.05)$ higher than values recorded on the un-amended soil of the University Research Farm at planting (Table 5).

Table 1. Mycoflora isolated from the wet and dry specimens of pig dung in Uyo, Nigeria and their brief taxonomy

\begin{tabular}{lll}
\hline Fungal organism & Fungal division & Fungal class and/or family \\
\hline Aspergillus candidus & Ascomycota & Euroticomycetes and Trichocomaceae \\
Sclerotium sp. & Basidiomycota & Agaricomycetes and Atheliaceae \\
Absidia sp. & Zygomycota & Mucoraceae \\
Acremonium sp. & Ascomycota & Hypocreaceae \\
Candida tropicalis & Ascomycota & Saccharomycetes \\
C. pseudotropicalis & Ascomycota & Debaryomycetaceae and Saccharomycetes \\
Rhizopus oryzae & Mucoromycota & Mucoraceae \\
\hline
\end{tabular}

Note: *Data are means of 3 determinations from two separate experiments

Table 2. Residual crude oil content and\% reduction of crude oil contents of the pig-dung amended and unamended soils

\begin{tabular}{cccc}
\hline Treatments & $\begin{array}{c}\text { Initial crude oil content of } \\
\text { flask }(\mathbf{m l})\end{array}$ & $\begin{array}{c}\text { Residual oil content } \\
(\mathbf{m l})\end{array}$ & $\begin{array}{c}\text { \% removal of crude oil from } \\
\text { amended soils }\end{array}$ \\
\hline 10\% pig dung-amended COCS & 1.00 & 0.475 & 52.84 \\
20\% pig dung-amended COCS & 1.00 & 0.407 & 59.29 \\
30\% pig dung-amended COCS & 1.00 & 0.291 & 70.86 \\
40\% pig dung amended COCS & 1.00 & 0.189 & 81.09 \\
0\% pig dung-amended COCS & 1.00 & 0.880 & 12.00 \\
LSD (0.05) & NS & 0.01 & 0.13 \\
\hline
\end{tabular}

Table 3. Heavy metal reduction (\%) of pig-dung amended and un-amended crude oil contaminated and uncontaminated soils and soybean plants

\begin{tabular}{|c|c|c|c|c|c|c|c|c|}
\hline \multirow{2}{*}{ Treatments } & $\mathbf{P b}$ & Cd & Fe & $\mathrm{Cr}$ & Zn & $\mathbf{C u}$ & As & Mean \\
\hline & \multicolumn{8}{|c|}{ Composition of heavy metals (ppm) in crude oil contaminated soil (COCS) } \\
\hline $10 \%$ pig dung-amended COCS & 2.68 & 2.43 & 601.12 & 14.08 & 121.11 & 3.26 & 1.35 & 106.57 \\
\hline $20 \%$ pig dung-amended COCS & 2.47 & 2.08 & 571.09 & 13.16 & 117.08 & 3.08 & 1.09 & 101.45 \\
\hline $30 \%$ pig dung-amended COCS & 2.16 & 1.52 & 502.16 & 12.09 & 102.13 & 2.74 & 0.78 & 89.08 \\
\hline $40 \%$ pig dung amended COCS & 1.96 & 1.47 & 308.03 & 8.94 & 88.03 & 2.11 & 0.45 & 58.71 \\
\hline $0 \%$ pig dung-amended COCS & 11.28 & 9.15 & 1001.21 & 45.16 & 163.19 & 6.52 & 2.17 & 176.95 \\
\hline \multirow[t]{2}{*}{$\operatorname{LSD}(0.05)$} & 0.08 & 0.41 & 1.26 & 0.17 & 1.04 & 0.05 & 0.02 & 2.78 \\
\hline & \multicolumn{7}{|c|}{ Composition of heavy metals (ppm) in soybean planted in (COCS) } & \\
\hline $10 \%$ pig dung-amended COCS & 2.51 & 2.26 & 590.21 & 13.26 & 101.02 & 3.02 & 1.02 & 101.90 \\
\hline $20 \%$ pig dung-amended COCS & 2.33 & 1.96 & 562.09 & 12.01 & 97.64 & 2.84 & 0.93 & 97.28 \\
\hline $30 \%$ pig dung-amended COCS & 2.01 & 1.39 & 489.25 & 10.69 & 92.18 & 2.25 & 0.51 & 85.67 \\
\hline $40 \%$ pig dung amended COCS & 1.68 & 1.18 & 274.68 & 6.72 & 71.73 & 1.92 & 0.06 & 51.14 \\
\hline $0 \%$ pig dung-amended COCS & 9.62 & 7.38 & 984.19 & 37.09 & 151.16 & 5.32 & 1.89 & 170.95 \\
\hline $\operatorname{LSD}(0.05)$ & 0.06 & 0.38 & 1.15 & 0.09 & 1.01 & 0.04 & 0.01 & 2.31 \\
\hline
\end{tabular}

Note: *Data are means of 4 determinations from 2 separate experiments 
Table 4. Effects of pig dung on yield and yield components of soybean sown on different levels of the amended COCS at 9 WAP

\begin{tabular}{ccccc}
\hline Treatments & $\begin{array}{c}\text { Plant height } \\
(\mathbf{c m})\end{array}$ & $\begin{array}{c}\text { Number of leaves } \\
\text { plant }^{-1}\end{array}$ & $\begin{array}{c}\text { Leaf Colour and } \\
\text { Appearance }\end{array}$ & Fresh weight plant- $^{\mathbf{(}(\mathrm{g})}$ \\
\hline 10\% pig dung-amended COCS & 34.72 & 12 & 2 & 53.21 \\
20\% pig dung-amended COCS & 36.66 & 14 & 2 & 56.09 \\
30\% pig dung-amended COCS & 40.50 & 15 & 3 & 61.18 \\
40\% pig dung amended COCS & 47.19 & 16 & 4 & 64.24 \\
0\% pig dung-amended COCS & 23.33 & 6.0 & 1 & 29.18 \\
LSD (0.05) & 0.16 & 0.04 & 0.01 & 0.34 \\
\hline
\end{tabular}

Note: *Data are means of 4 replicates from 2 separate experiments

Table 5. Physical and chemical properties of the pig dung-amended and un-amended crude oil contaminated soils (COCS) at 1 and 13 weeks after amendment (WAA)

\begin{tabular}{|c|c|c|c|c|c|c|c|c|c|c|}
\hline \multicolumn{11}{|c|}{ Rates of dung application (\%), time of analysis (weeks); and mineral composition of COCS } \\
\hline & \multirow{2}{*}{$\begin{array}{c}\text { 0\% pig } \\
\text { dung }\end{array}$} & \multicolumn{2}{|c|}{$10 \%$ pig dung } & \multicolumn{2}{|c|}{$20 \%$ pig dung } & \multicolumn{2}{|c|}{$30 \%$ pig dung } & \multicolumn{2}{|c|}{$40 \%$ pig dung } & \multirow{2}{*}{$\begin{array}{r}\text { LSD } \\
(\mathbf{0 . 0 5}) \\
\end{array}$} \\
\hline & & WK 1 & WK 13 & WK 1 & WK 13 & WK 1 & WK 13 & WK 1 & WK 1 & \\
\hline Texture & SL & SL & SL & SL & SL & SL & SL & SL & SL & Nil \\
\hline $\mathrm{pH}$ (water) & 4.34 & 6,66 & 6.00 & 6.80 & 6.40 & 7.01 & 6.60 & 7.24 & 6.68 & 0.22 \\
\hline Total nitrogen (\%) & 0.23 & 1.77 & 0.92 & 2.21 & 1.03 & 2.48 & 1.15 & 2.50 & 1.60 & 0.01 \\
\hline Organic carbon $(\%)$ & 1.45 & 6.21 & 0.99 & 6.50 & 1.12 & 6.88 & 1.34 & 7.01 & 1.45 & 0.13 \\
\hline Organic matter $(\%)$ & 2.16 & 9.00 & 4.44 & 9.14 & 4.51 & 9.25 & 4.61 & 9.40 & 4.70 & 0.34 \\
\hline Phosphorus (mg/kg) & 29.82 & 78.29 & 58.01 & 80.02 & 59.04 & 81.16 & 60.21 & 82.00 & 61.09 & 1.23 \\
\hline Calcium $(\mathrm{Cmol} / \mathrm{kg})$ & 1.74 & 3.30 & 2.23 & 3.35 & 2.28 & 3.42 & 2.30 & 3.50 & 2.34 & 0.06 \\
\hline Magnesium (Cmol/kg) & 1.20 & 2.89 & 2.15 & 3.25 & 2.21 & 3.31 & 2.25 & 3.44 & 2.28 & 0.04 \\
\hline Potassium $(\mathrm{Cmol} / \mathrm{kg})$ & 1.01 & 4.00 & 2.20 & 4.03 & 2.34 & 4.20 & 2.50 & 4.53 & 2.55 & 0.01 \\
\hline Sodium $(\mathrm{Cmol} / \mathrm{kg})$ & 0.24 & 1.12 & 1.01 & 1.20 & 1.17 & 1.30 & 1.20 & 1.36 & 1.23 & 0.11 \\
\hline $\operatorname{LSD}(0.05)$ & 0.43 & 0.50 & 0.42 & 0.79 & 0.44 & 0.91 & 0.63 & 1.02 & 0.68 & Nil \\
\hline
\end{tabular}

Note: *Data are means of 4 determinations from 2 separate experiments; SL: sandy loam; WK: weeks

\section{Discussion}

The fungi namely Aspergillus candidus, Sclerotium sp., Absidia sp., Acremonium sp., Candida tropicalis, $C$. pseudotropicalis and $R$. oryzae were found associated with wet and dry specimens of pig dung in this study. High presence of nutrients especially carbon, vitamins, fibers (cellulose, hemicelluloses and lignin) and minerals coupled with adequate $\mathrm{pH}$ and water tension in dungs, may be the reason for this association. Heterotrophic fungi belonging to the genera Aspergillus, Penicillium, Mucor, Rhizopus, Alternaria, Beauveria, Paeclomyces, and Candida have been found to be dung-loving and to tolerate oilcontaminated environments (Dawodi et al. 2015; Ughamba et al. 2019). Findings from this work corroborate the report of several workers who found Candida sp., C. tropicalis, Rhizopus sp., Mucor sp., Aspergillus spp., A. niger to be strongly associated with cow and pig dung (Obire et al. 2008; Zhou et al. 2016; Samuel et al. 2017). It also conforms to submissions of Jeanjitt et al. (2006) who reported association of $A$. candidus, A. niger, F. solani, Cephaliophora irregularis, and Nigrospora oryzae with dung of some non-ruminants mammals. High incidences of 98\%, 86\% and 78\% for Aspergillus spp., Rhizopus spp., and Mucor spp. respectively on non-ruminant dung by Imran et al. (2014) further support our findings in this work.

A wide variety of members of fungal divisions are found on dung; the Mucoromyceta (Zygomyceta) usually appear first, followed by Ascomycota and then the
Basidiomycota. Presentations in Table 1 indicated that three fungal divisions colonized the test dung specimens; these were saprobes of the division Ascomycota, Mucoromyceta and Basidiomycota. This finding is supported by recent evaluations by other workers on poultry, cow and pig dungs who reported the interaction of members of Zygomycota and Ascomycota with these specimens (Imran et al. 2014). Earlier works by Webster (1970) Richardson (1972, 2001b, 2004, 2008) on association of coprophilous fungi with different dung types found up to 137 Ascomycetes on the dung samples of both ruminant and non-ruminant animals used for the study. This further lends conformity to the findings from this study where about $57.14 \%$ of the entire saprobes incident on the test dung specimens were Ascomycetes.

Fungal species compositions and the species diversities on the different dung substrates are largely influenced by the feeding habits and food preferences of animals. The less selective the feeding habit, the larger the diversity of coprophilous fungal species on the dung substrate (Krug and Jeng 1995; Ebersohn and Eicker 1992). Types of digestive systems and variations in animal nutrition, geographical location, and moisture content of the excrements, $\mathrm{pH}$, metabolites, and intra and inter-specific competitions can also influence the fungal make-up of feces (Dix and Webster 1995; Ebersohn and Eicker 1997). The highest occurrence $(80 \%)$ of C. pseudotropicalis observed from this study is an indication that fungi are active coprophilous organisms, whose activity in dung is 
adversely affected by water tension of the substrate (Figure 1). It may also be that $\mathrm{pH}$ differences or differential contents of certain inhibitory metabolites between the wet and the dry dung specimens may account for differences in incidence of the saprobes on the test dung.

Results in the present study showed that remediating COCS with pig dung had significant effects on crude oil content of the test soils. It showed that the treatments sufficiently reduced the crude oil content of the contaminated soils. This finding is consistent with the reports by Nwaogu et al. (2015), who found that amendment of COCS with goat dung resulted in removal of $62.08 \%$ of total petroleum hydrocarbon compared to $8.15 \%$ in untreated control. Observations from this study also agree with Njumbemere et al. (2020), and Ugwuoha et al. (2020), who recorded $82.55 \%-90.00 \%$ removal of diesel and crude oil from contaminated soils amended with different levels of pig dung within six weeks respectively. Furthermore, data from this study agree with greater than $60 \%-68.2 \%$ removal of used engine or Lagoma oil by 5 $10 \%$ pig dung amendment in the treated than untreated crude oil-contaminated soils (Yakubu 2010; Naowasarn and Leungpasert 2016), and with 25\% inoculation of Pleurotus ostreatus which reduced diesel contamination in liquid medium from greater than $12,000 \mathrm{ppm}$ to less than $200 \mathrm{ppm}$ in 16 weeks (Stamets 2010).

Fungi and yeast are well-known natural agents of decomposition of organic matter such as cellulose, hemicellulose and lignin substrates. They are also reported as great degraders of hydrocarbons (Kumar and Kaur 2019; Khartoom and Jilliani 2021). Mycotic coprophils from pig dung used in this study, exhibited significant ability to tolerate, grow, and proliferate actively in the amended soil; using hydrocarbons as major sources of calories. These organisms secreted many oxidative enzymes, organic acids, chelators, and extracellular enzymes that broke down cyclic and aliphatic xenobiotics in the soil (Medaura et al. 2021). In fact, up to 120 novel enzymes that can degrade a wide range of hydrocarbons have been isolated from several fungi (Stamets 2010). These enzyme-arsenals including laccases and lignin peroxidases exhibit low substrate specificity and could participate in the breakdown of a wide spectrum of organic compounds and hydrocarbons (D’Annibah et al. 2006).

The content of residual oil in the pig dung-amended COCS decreased with increasing levels of the soil amendment with pig dung. This is supported by the report of Samuel et al. (2018), who noted the same trend in their own study. Several workers are of the view that the success of bio-remediation depended not only on the type, but also on the level of dung used in the study (Stamets 2010; Adekunle and Ataga 2014). These factors influenced the microbial community's population and the level of enzymes-complex in remediated environments. Mammalian dung are thought to naturally supply and/or stimulate their inherent microbial populations in treated soils, providing metabolites that activate hydrocarbondegrading fungi, and ultimately leading to significant decrease in crude oil in amended soils (Udebuani et al. 2012; Nwaogu et al. 2015). Adekunle and Ataga (2014) hypothesized that effective degradation of complex mix of hydrocarbons involved more than a single fungal species. These researchers reported that cultures containing multiple fungi-mixes were more effective than a single fungus in degrading crude oil. Similarly, Stamets (2010) noted that mixing $P$. ostreatus, farmyard waste and wood chippings resulted in far greater degradation of hydrocarbon than the fungus or compost alone. The low content of residual crude oil in the dung amended COCS in this study may have been due to the complex mix of fungi and heterotrophic nature of materials in the test dung.

The presence of heavy metals $(\mathrm{Pb}, \mathrm{Cd}, \mathrm{Cr}, \mathrm{Fe}, \mathrm{Zn}, \mathrm{As}$ and $\mathrm{Cu}$ ) with the exception of $\mathrm{Zn}$ and $\mathrm{Fe}$ in trace degrees in the crude oil contaminated soil and soybean specimens was found in the present study. This is in conformity with the reports of Osuji et al. (2010) who noted trace amounts of these metals and metalloids in crude oil contaminated soil sediments in Ebocha, Niger Delta area of Nigeria. In addition, arsenic was recorded at about $2.17 \mathrm{ppm}$ in the unamended COCS samples (Table 3). Soil sediments with presence of arsenic at less than $50 \mathrm{ppm}$ are considered ecologically healthy (Strivastava et al. 2015). Though high levels of zinc and iron were detected in this study, they do not however seem to pose harmful threats to human health since they are required for proper heme formation, to boost and maintain energy, immunity and vitality in humans (Enyiukwu et al. 2018).

The pig dung amendments had significant effects on heavy metal contents of treated COCS and the test soybean plant. It showed that the coprophils sufficiently reduced the degree of heavy metal composition of treated COCS. Ecosystems contaminated by crude oil over a long time are known to be characteristically associated with presence of heavy metals in soils and plants growing on them (Adams et al. 2017; Cocarta et al. 2017). Filaments of certain heterotrophic fungi are reported to possess a very high ability to immobilize or degrade toxic heavy metals through adsorption or chelation into melanin-like polymers; or by insolubilizing them as metal oxalates. (D'Annibale et al. 2006). For instance, dissolved (arsenite III) ions are immobilized to arsenate V) by some fungal filaments (Stivastava et al. 2015). These heterotrophs secrete a wide pool of oxidative and extracellular enzymes (laccases and lignin peroxidases) which they also employ to degrade stubborn bonds in polycyclic aromatic hydrocarbons (PAH) and total petroleum hydrocarbons (TPH) in soils (D'Annibale et al. 2006). The low presence of heavy metals in the pig dung amended COCS and root specimens of soybean planted in the treated COCS compared with the control may have been due to these activities of fungal filaments and enzymes. Findings in this study in which remediating COCS with pig dung sufficiently deceased heavy metal contents of the dung amended soil is consistent with the views of Adams et al. (2017), who found rice husk amendment of COCS, to significantly reduce heavy metal contents of COCS than chicken manure amended soils. Pig dung and rice husk are coarser than chicken; and the higher degree of coarseness of these materials (probably due to higher contents of lignin, cellulose, and hemicellulose) is suggested to readily 
provide higher levels of electron-accepting capacity that increases the rate of biodegradation of pollutants (Adams et al. 2017) than chicken manure. The high efficacy of pig dung in reducing heavy metals and crude oil contents of the test soil may be due to this fact. D'Annabale et al. (2006) reported that filamentous fungi immobilize toxic heavy metals through chelation or absorption into melanin-like polymers using armies of extracellular enzymes (laccases and lignin peroxidases). Perhaps, ability of the pig dung coprophils to secrete a plethora of enzymes that have capacity to immobilize or chelate toxic heavy metals into non-toxic organic polymers may be the reason for the reduction of heavy metals present in treated soils in this study.

The pig dung amendments of the COCS increased the total seed germination, seedling emergence and vigor in a dose-wise manner. This observation is congruent with the reports of Obire et al. (2008) and Samuel et al. (2018), who found that maize and bean seeds planted on increasing levels of pig dung amended COCS; germinated, grew and performed significantly and correspondingly well to the level of pig dung amendment in the contaminated soil, compared to the untreated control where the crop failed to grow well. It is also consistent with Enyiukwu and Ononuju (2016) findings, who in a parallel study found that the vigor of cowpea seedlings was directly proportional to the corresponding increase in concentration of plantderived seed treatments. Organic matter in amended soils is known to improve soil structure, texture and aeration, which in turn made for increased microbial population and activity (Ughamba et al. 2019). Several researchers have noted that soil amendments with agro-wastes encouraged increase in the population of heterotrophic fungal species in the soil; leading to increased release of nitrates, and other elemental nutrients in the treated soil. The addition of the pig dung acted not only in adding organic matter directly into the treated COCS, but mainly as a means of biostimulating the COCS to favor the growth and population of target potential crude oil utilizing fungi which have inherent capacity to degrade and use crude oil as an integral source of carbon and calories (Obire et al. 2008; Deshmukh et al. 2016; Samuel et al. 2017). Thus, the minerals, particularly nitrogen and phosphorus, may have been adsorbed on such soils (Udebuani et al. 2012); were made available to and easily taken up by the crop, which translated to better growth and vigor the treated crop, compared to the control. Also, diverse microbes in dung produce different physiologically active metabolites (Gupta et al. 2016). Phenols from breakdown of dung of mammalian farm animals in amended soils play a role in suppressing the growth of soil-dwelling parasitic nematodes; and this nematicidal activity may have contributed to the enhanced vigour of the soybean seedlings in the amended COCS than the control experiment (Enyiukwu and Awurum 2013; Li et al. 2014).

The yield (fresh biomass) and yield components (plant height, number and color of leaves, and vigor) of seedlings from the amended COCS were significantly higher in a dose-dependent manner than those of the untreated control experiment (Table 4). Gupta et al. (2016) reported that dung-borne fungi contribute to increased soil fertility through phosphate solubilization. In so doing, they release some compounds of nitrogen, phosphorus and potassium amongst others which were adsorbed on contaminated soils matrices (Hussein 2018). According to Ogunsola and Adetunji (2016) N, P, K and S have been rated as the major nutrients in tropical soils; though $\mathrm{N}$ and $\mathrm{P}$ present the most limiting edaphic factors in arable crop production in most African Soils. Nitrogen is a vital factor in the nutrition of higher plants. It is reported as a characteristic and major constituent of chlorophyll and enzymes. As such it wades substantial influence on crop growth, performance and yield. Similarly, phosphorus also plays important role in many enzyme-assisted reactions. Especially concerning rigidity, phosphorus strengthens the skeletal structures of the crop; preventing lodging and increasing resistance of plants to microbial diseases (Maqsood et al. 2001; Onasanya et al. 2009; Imran et al. 2016). Phosphorus is essential for cell division and proper meristematic activity in plants. Therefore, the level of $\mathrm{P}$ in the growth medium of plants impacts their leaf color, leaf area, number of leaves, and seed and tuber development (Ogunsola and Adetunji 2016). Findings in this study where pig dung amendment significantly improved the yield and yield components of soybean is consistent with the report of Samuel et al (2018) who found that COCS amended with mammalian dung produced higher biomass and better quality bean crop than what was obtained from the untreated control experiment. It also agrees with Ogboghodo et al. (2004) and Obire et al. (2008) that remediating petroleum polluted agricultural soils with pig dung and poultry dropping respectively, significantly $(\mathrm{P} \leq 0.05)$ enhanced the performance of maize (Zea mays L.) than the un-amended control.

Compared to untreated controls Graham et al. (2013) reported significant changes in the microbial community in dung-amended soils involving Candida, Aspergillus, Fusarium, Penicillium, and related fungi leading to higher microbial biomass and activity, decreased pathogen-flora, and decreased plant disease due to polycyclic aromatic hydrocarbons (PAH) and heavy metals toxicity on test crops. The ability of the pig dung to stimulate fungal heterotrophs in this study to grow effectively and secrete army of enzymes to degrade crude oil, suppress PAH and heavy metals toxicity; solubilize phosphorus and nitrogen locked up on the soil particles of the COCS may explain the better and greater performance in terms of height, number of leaves, leaf color and biomass accumulation of the crop on the treated than the untreated control.

Dung and other agro-derived wastes improve the physical and chemical properties as well as microbial populations in soils (Amaechi et al. 2018; Ojo-omoniyi et al. 2020). Presence of nitrogen, sodium, magnesium, and potassium as well as organic carbon and organic matter amongst other nutrients were observed in low quantities in the un-amended pre-experiment soil (Table 5). This is congruent with Ikeogu and Nwaofia (2013) submission who also found these elements in low amounts in unamended soil of Umudike and Amakama, Southeast Nigeria. High aluminum toxicity, bio-unavailability of carbon, nitrogen and phosphorus characterize COCS, and 
these constraints were sufficiently overcome by pig dung amendments in a trial (Ojo-Omoniyi et al. 2020). Findings in this study revealed increases in content of organic carbon, organic matter, $\mathrm{K}, \mathrm{P} \mathrm{N}$ in the amended COCS; harmonizing with reports of Ojo-Omoniyi et al. (2020) who found these parameters to increase in COCS amended with pig dung. Our observations that sodium was low in the pig dung-treated soil was also in harmony with Ojo-Omoniyi et al. (2020) who found in a trial that pig dung amended soils recorded less sodium content than goat dung-amended soil. Substantial dose-wise increases in the values of nitrogen, phosphorus, potassium and other nutrient contents of the pig dung-amended soil were observed in this study at planting. Zhang et al. (2020) reported that microbial enzymes activity and soil fertility increased in agro-waste remediated COCS in dose-dependent manner. Also, Samuel et al. (2018) noted that increasing concentration of pig dung in amended COCS increased the values of these parameters in a directly proportional manner. However, the decreased values of these parameters in the amended COCS at harvest confirm that the activities of the dungassociated fungi in the amended COCS released and encouraged uptake of nutrients by the soybean seedlings (Table 3). This also agrees with Samuel et al. (2018) who found a similar downward trend in nutrient values of the respective parameters at harvest in the pig dung-amended COCS planted to beans. Nutrient removal or uptake by soybean seedling stands out as the explanation for these observed disparities in pre- and post-experiment nutrient status of amended COCS in this study.

In conclusion, disposal of agricultural wastes especially mammalian dung remains a serious challenge in developing worlds. Also, rising exploration of crude oil and dependence on oil-based energy increasingly constitutes environmental pollution challenges particularly in the Niger Delta areas of Nigeria. The excreta of pigs are suitable agricultural manure known and used over the years for soil fertility improvement. As manure, pig dung is a good substrate for growth of various microorganisms especially saprophytic fungi which decompose them and release nutrients and minerals locked up in them into amended soils, to improve crop performance and yield. These saprophytes have capacity to degrade petroleum hydrocarbons. Against the backdrop of ravaging instances of oil pollution, studies suggest that the application of mammalian dung as soil amendments could offset negative effects of oil spillage in arable and mangrove environments. It becomes obvious from this study that pig dung in dry state holds strong potentials for environmental bio-remediation interventions since they encourage high incidence profile of recalcitrant long-chain polymer degrading fungi and hydrocarbon detoxifying mycoflora. This study showed that pig dung reduced crude oil pollution in soils between $50-85 \%$ in 2 months, significantly reduced heavy metal contamination, improved the seed germination and growth, seedling vigor and total performance of the tested soybean.

\section{REFERENCES}

Abdullah SK. 1982. Coprophilous mycoflora on different dung types in Southern Desert of Iraq. Sydowia 35: 1-5.

Adams FV, Niyomugbabi A, Sylvester OP. 2017. Bioremediation of crude oil contaminated soil using agricultural wastes. International Conference on Sustainable Materials Processing and Manufacturing SMPS, Kruger National Park, January 23-25, 2017. Procedia Manufacturing 7: 459-464. DOI: 10.1016/j.promfg.2016.12.037.

Adesina GO, Adelesoya KA. 2014. Effect of crude oil pollution on heavy metal contents, microbial population in soil, and maize and cowpea growth. Agric Sci 5 (1): 43-50. DOI: 10.4236/as.2014.51004.

Akhtar N, Amin-ul Mannan M. 2020. Mycoremediation: Expunging environmental pollutants. Biotechnol Rep 26: e00425 DOI: 10.1016/j.btre.2020.e00452.

Amaechi AK, Chidubem C, Mike GR, Ebere O. 2018. Analysis and optimization process of goat dung as potential co-substrate in bioremediation. Alex Eng J 59 (4): 3053-3066. DOI: 10.1016/j.aej.2018.05.004

Bada BS, Egbeja TI, Awolowo TA, Obuotor TM. 2019. Degradation of total petroleum hydrocarbon in petroleum products contaminated soils using pig dung. West Afr J Appl Ecol 27 (2): 1-15.

Barnett HL, Hunter BB. 1995. Illustrated Genera of Imperfect Fungi (3rd Ed). Burgess Publishing Company, Minneapolis.

Bell A. 1983. Dung fungi: An illustrated guide to coprophilous fungi in New Zealand. Victoria University Press, Wellington, New Zealand.

Bell A. 2005. An illustrated guide to the coprophilous ascomycetes of Australia, CBS, Utrecht. Czech Mycol 59 (1): 82.

Bills GF, Gloer JB, An Z. 2013. Coprophilous fungi: Antibiotic discovery and functions in an underexplored arena of microbial defensive mutualism. Curr Opin Microbiol 16: 1-17. DOI: 10.1016/j.mib.2013.08.001.

Cocarta M, Stoin MA, Karademoru A. 2017. Crude oil contaminated sites: Evaluation by using risk assessment approach. Sustainability 9: 1365. DOI: $10.3390 / \mathrm{su} 9081365$.

Cohen R, Hader Y. 2009. Roles of fungi in agricultural waste conversion. In: Gadd GM (eds). Fungi in bioremediation. British Mycological Society Vol. 23, Cambridge, UK.

Countryside (Anonymous) 2012. Importance of fungi. www.countryscientific.co.uk/fungi/importance. [July 12, 2012].

D’Annibale A, Rosetto F, Leonardi V, Federaci F, Petriccioli M. 2006. Role of autochthonous filamentous fungi in bioremediation of a soil historically contaminated with aromatic hydrocarbon. Appl Environ Microbiol 72(1):28-36. DOI: 10. 1128/AEM.72.1.28-36.2006.

Dawodi V, Madami M, Tahmourespour A, Golshani Z. 2015. The study of heterotrophic and crude oil utilizing soil fungi in crude oil contaminated regions. J Bioremed Bioegrad 6: 270 DOI: 10.4172/2155-6199-1000270.

Deshmukh R, Anshuman AK, Purohit A. 2016. Diverse metabolic capacities of fungi for bioremediation. Indian J Microbiol 56(3): 247264. DOI: 10.1007/s12088-016-0584-6.

Dix NJ, Webster J. 1995. Fungal Ecology Chapman and Hall, London. DOI: 10.1007/978-94-011-0693-1.

DPI (Department of Primary Industries, NSW) 1999. The causes of soil acidity. Dpi.nsw.gov. [February 12, 2021].

Ebersohn C, Eicker A. 1992. Coprophilous fungal species composition and species diversity on various dung substrate of African game animals. Bot Bull Acad Sin 33: 85-95.

Ebersohn C, Eicker A. 1997. Determination of the coprophilous fungi fruit body successional phases and the delimitation of species association classes on dung substrates of African game animals. Bot Bull Acad Sin 38: 183-190.

Echeverrigarray S, Zacaria J, Beltran R. 2010. Nematicidal activity of monoterpenoids against the root-knot nematode Meloidogyne incognita. Phytopathology 100 (2): 199-203. DOI: 10.1094/PHYTO100-2-0199.

Enyiukwu DN, Amadioha AC, Ononuju CC. 2021. Antifungal activities of methanol extracts of some medicinal plants against germination and growth of Colletotrichum destructivum O'Gara in culture. Asian J. Natural Products Biochemistry 10 (1): 25-29.

Enyiukwu DN, Amadioha AC, Ononuju CC. 2018. Significance of cowpea leaves for human consumption. Greener Trends Food Sci Nutr 1 (1): 1-10. DOI: 10.15580/GTFSN.2018.1.061818085.

Enyiukwu DN, Awurum AN. 2013. Fungitoxic principles and in vitro antifungal activity of extracts from Carica papaya and Piper 
guineense on Colletotrichum destructivum. Continental J Biol Sci 6 (1): 29-36.

Enyiukwu DN, Ononuju CC. 2016. Comparative priming effects of phytochemicals from Piper guineense and Alchornea cordifolia on cowpea (Vigna unguiculata L. Walp.) seeds. J Pests Plant Sci 3 (1): 1-4.

Enyiukwu DN. Awurum AN. 2012. Comparative fungitoxicity of benomyl and extracts of Carica papaya roots and seeds and Piper guineense seeds on Colletotrichum destructivum O'Gara. Continental J Biol Sci 5 (1): 26-31.

Erdogan EE, Karaca A. 2011. Bioremediation of crude oil-polluted soil Asian J Biotechnol 3: 206-213. DOI: 10.3923/ajbkr.2011.206.213.

Giwa OE, Ibitoye FO. 2017. Bioremediation of heavy metals in crude oil contaminated soil using isolated indigenous microorganisms cultured with E. coli DE3 BL21. Intl J Eng Appl Sci 4(6): 67-70.

Graham E, Grandy S, Thelen M. 2013. Manure effects in soil organisms and Soil Quality. MSU Extension In: Emerging Issues in Animal Agriculture. www.can.msu/emerging. Accessed June 12, 2019.

Gupta KK. Amaja KR, Rana D. 2016. Current status of cow dung as bioresource for sustainable development. Bioresour Bioprocess 3: 28. DOI: 10.1186/s40643-016-0105-9.

Hussein AN. 2018. Role of fungi in bioremediation. Adv Biotechnol Microbiol 24 (1): DOI: 10.19880/AJBM/2019.12555841.

Ikeogu UN, Nwofia GE. 2013. Yield parameters and stability of soybean \{Glycine $\max (\mathrm{L}$.) Merril\} as influenced by phosphorus fertilizer rates in two utisols. J Plant Breed Crop Sci 5 (4): 54-63. DOI 10.5897/JPBCS12.014.

Imran A, Khan AA, Inam I, Ahmed F, Mord T. 2016. Yield and yield attributes of mung bean (Vigna radiata L.) cultivars as affected by phosphorus levels under different tillage systems. Cogent Food Agric 2 (1): 1151982. DOI: $10.1080 / 23311932.2016 .1157982$

Imran SG, Razugi NS, Aziz GM. 2014. Isolation and Identification of fungi located in horse manure. Indian J Appl Res 4 (8): 272-274. DOI: $10.15373 / 2249555 \mathrm{X} /$ August2014/69.

Iwegbue CMA 2011. Assessment of heavy metals speciation in soils impacted with crude oil in the Niger Delta, Nigeria. Chem Special Bioavailab 23 (1): 7-15. DOI: 10.3184/095422911X12964002282100.

Jeanjitt O, Manoch L, Visarathanonth N, Chamswarng C, 2006. Diversity and distribution of hyphomycetes from dung in Thailand. Witthayasan Kasetsart 40: 890-901

Khartoon H, Jilliani A. 2021. Role of fungi in bioremediation of contaminated soils. In: Sharma VK, Shah M, Parmar S, Kumar A (eds). Fungi Bio-Prospects in Sustainable Agriculture, Environment and Nanotechnology Vol. 2. Extremepophilic Fungi and MycoMediated Environmental Management. Elsevier, Netherlands.

Krug JC, Jeng RS 1995. A new coprophilous species of Podosordaria from Venezuela. Canadian J Bot 73: 65-69. DOI: 10.1139/b95-008.

Lu H, Wang H, Zhung K, Xu Y, Li G. 2014. Identification and nematicidal activity of bacteria isolated from cow dung. Ann J Microbiol 64: 407-411. DOI: 10.1007/s13213-013-0660-7.

Maqsood M, Abod AA, Igbal A, Hussain I. 2001. Effects of variable rates of nitrogen and phosphorus on the growth and yield of maize (Golden). Online J Biol Sci 1 (1): 19-20. DOI: 10.3923/jbs.2001.19.20.

Medaura MC, Guivernau M, Moreno-Ventas X, Prenafeta-Boldú FX, Marc Viñas 2021. Bioaugmentation of native fungi, an efficient strategy for the bioremediation of an aged industrially polluted soil with heavy hydrocarbons. Front Microbiol. DOI 10.3389/fmicb.2021.626436

Naowasarn S, Leungprasart S. 2016. Bio-remediation of oil-contaminated soil using chicken manure. Soil Sediment Contam 25(9): 739-756. DOI: 10.1080/15320383.2016.12139699.

Njumbemere N. Ifelebugu A, Onyedikachukwu NB. 2020. A comparative assessment of pig manure and poultry manure in the biodegradation of diesel contaminated soil. J Energy Res Rev 4(3): 1-13. DOI: 10.9734/jemrr/2020/v43301.

Nwagbo G. 2017. Oil pollution in the Niger Delta. Stanford University, Fall, 2017. large.standord.edu/courses/2017/PG240/nwagbo/... [June $16,2021]$.

Nwaogu CP, Azubuike CC, Ogugbue CJ. 2015. Enhanced bioremediation of soil artificially contaminated with Copra aegagrus hircus (Goat) manure. Biotechnol Res Int 2015: 1-7. DOI: 10.1155/2015/657349.

Obire O, Anyanwu EC, Okigbo RN, 2008. Saprophytic and crude oildegrading fungi from cow dung and poultry droppings as bioremediation agents. J Agric Technol 4 (2): 81-87.
Ogboghodo IA, Erebor EB, Osenwota JO, Isitekhole HH. 2004. The effects of application of poultry manure to crude oil-polluted soils on maize (Zea mays L.) growth and soil properties. Environ Monit Assess 96 (3): 153-161. DOI: 10.1023/B:EMAS.0000031724.22352.af

Ogunsola KE, Adetunji M. 2016. Effects of phosphorus and sulphur on dry matter yield of maize (Zea mays L.) in some soils at Abeokuta, Ogun State, Nigeria. Agro Sci 15(2): 1-8. DOI: 10.4314/as.v15i2.1

Ojo-Omoniyi AO, Dike-Eke N, Owoeye OA. 2020. Comparative study of enhanced crude oil degradation in 3 tropical soils using pig and goat manures as organic amendment. Intl J Curr Microbiol Appl Sci 9(8): 2317-2329. DOI: 10.20546/ijcmas.2020.908.266.

Onasanya O, Ayelasi OP, Amos O, Oikeh SO. 2009. Growth and yield response of maize (Zea mays L.) to different rates of nitrogen and phosphorus fertilizers in Southern Nigeria. World J Agric Sci 5 (4): 400-407. DOI: 10.3923/ijar.2009.193.203.

Orji FA, Ibiere AA, Dike EN. 2012. Laboratory scale bioremediation of petroleum hydrocarbon polluted mangrove swamp in the Niger Delta using cow dung. Malays. J Microbiol 8: 219-228.

Richardson MJ. 1972. Coprophilous ascomycetes on different dung types. Trans Brit Mycol Soc 58: 37-48. DOI: 10.1016/S00071536(72)80069-X.

Richardson MJ. 2001a. Coprophilous fungi from Brazil. Braz Arch Biol Technol 44 (3): 283-289. DOI: 10.1590/S1516-89132001000300010.

Richardson MJ. 2001b. Diversity and occurrence of coprophilous fungi. Mycol Res 105: 387-402. DOI: 10.1017/S0953756201003884.

Richardson MJ. 2004. Coprophilus fungi from Keland. Acta Bot Islandica 14: $77-102$

Richardson MJ. 2008. Records of coprophilous fungi from the lesser Antilles and Puerto Rico. Caribbean J Sci 44 (2): 206-214. DOI: 10.18475/cjos.v44i2.a8.

Samuel O, Chukwu S, Fredrick O. 2017. Bio-deterioration potentials of microorganism isolated from pig manure obtained at Awka, Nigeria. Nat Resour Conserv 5 (3): 33-43. DOI: 10.13189/nrc.2017.050301.

Samuel O, Chukwu S, Fredrick O. 2018. Effects of pig manure on the microbial remediation of crude oil-polluted soil. Am J Life Sci Res 6 (2): 76-90.

Stamets P. 2010. The petroleum problem: Mycoremediation and its application to oil spills. Fungi.com/blog/article. [March 15, 2021].

Strivastava A, Gosh D, Bose S. 2015. Arsenic contamination in soils and sediments in India. Curr Pollut Rep 1: 35-46. DOI: 10.1007/s40726015-0004-2

Thilagam L, Nayak BK, Nanda A. 2015. Studies on the diversity of coprophilous micro-fungi from hybrid cow dung samples. Intl $\mathbf{J}$ Pharmtech Res 8 (9): 135-138.

Udeani AC, Okoli CI, Nwigwe WC, Ozoh PTE. 2012. The value of animal manure in the enhancement of bioremediation process in petroleum hydrocarbon contaminated agricultural soils. J Agric Technol 8 (6): 1935-1952.

Ugboma CJ, Sampson T, Mbonu NE 2020. Bioremediation of heavy metals from artisanal crude oil refinery (kpo-fire) impacted soil using Bacillus flexus and Pseudomonas aeruginosa in Ngie community, Degema Local Government Area, Rivers State, Nigeria. J Appl Sci Environ Manage 24 (12): 2049-2050. DOI: 10.4314/jasem.v24i12.2.6.

Ughamba KT, Nnaji ND, Ogbonna KE, Anyanwu CU. 2019. Pig dropping: A potential bio-stimulatory candidate for bioremediation of diesel oil-polluted soil. J Food Agric Environ 4 (6): 1933-1942. DOI: 10.22161/ijeab.46.44

Ugwoha E, Amah VE, Oweh GO. 2020. Bio-remediation of crude oil contaminated soil using pig droppings and bone char. J Adv Biol Biotechnol 23 (8): 13-24. DOI: 10.9734/jabb/2020/v23i830170.

Webster J. 1970. Coprophilous fungi. Trans Brit Mycol Soc 54: 161-180. DOI: 10.1016/S0007-1536(70)80030-4.

Yakubu MB. 2010. Biodegradation of Lagoma crude oil using pig dung. Afr J Biotechnol 6(24): 2821-2825. DOI: 10.5897/AJB2007.000-2450

Zhang C, Wu D, Ren H. 2020. Bio-remediation of oil-contaminated soil using agricultural wastes via microbial consortium. Sci Rep 10: 9188. DOI: $10.1038 / \mathrm{s} 41598-020-66169-5$.

Zhang H. 2017. Causes and effects of soil acidity. Oklahoma State University Extension. Extenson.okstate.edu. Article ID PSS-2239. [February 12, 2021].

Zhou J, Wang L, Wang H. Jiang L, Jiang X. 2016. Effects of different ratios of pig manure to fungus residues on physicochemical parameters during composting. J Air Waste Manag Assoc 66(5): 313321. DOI: 10.80/10962247-2016.1149526. 